\title{
Enhancement diesel oil degradation by using biofilm forming bacteria on biochar
}

\author{
Nghiên cứu hiệu quả xủ lý dầu diesel của các chủng vi khuẩn tạo màng sinh \\ hoc trên chất mang than sinh học
}

Research article

Le Thi Nhi Cong ${ }^{1}{ }^{2}$, Cung Thi Ngoc Mai ${ }^{1}$, Vu Ngoc Huy ${ }^{1}$, Do Thi Lien ${ }^{1}$, Do Thi To Uyen ${ }^{1}$, Nguyen Thi Minh ${ }^{1}$, Hoang Phuong Ha ${ }^{1}$

${ }^{I}$ Institute of Biotechnology, Vietnam Academy of Science and Technology, 18 Hoang Quoc Viet, Cau Giay, Ha Noi, Vietnam; ${ }^{2}$ Graduate University of Science and Technology, Vietnam Academy of Science and Technology, 18 Hoang Quoc Viet, Cau Giay, Ha Noi, Vietnam

\begin{abstract}
Biochar is defined as a carbon-rich, fine-grained, porous substance, which is produced by pyrolysis biomass with little or no oxygen. Biochar is usually produced from crop residues, wood biomass, animal litters, and solid wastes. Recently, biochar is increasingly receiving attention as an environmental-friendly approach, especially as a climate change mitigation strategy. Biochar is especilly demonstrated to remove diesel oil (DO) from soil and water. In this report, 4 biofilm forming bacteria including Klepsiella sp. VTD8, Pseudomonas sp. BQN21, Rhodococcus sp. BN5 and Stenotropomonas sp. QND8 were used to attach to biochar produced from husk to estimate the capacity of their DO removal. As the results, removal efficiency of biofilm formed by each strain VTD8, BQN21, BN5 and QND8 were 67, 73, 75 and $68 \%$ with initial concentration of $39 \mathrm{~g} / 1$, respectively. On the other hand, mix species biofilm attached to husk carrier and without carrier degraded 98 and $78 \%$. Using husk without bacteria as absortion control, the amount of DO removal was $23 \%$. These results gave hint that using biochar produced from husk as carrier for biofilm forming bacteria to attach may increase efficiency of DO pollution treatment.
\end{abstract}

Than sinh họ (biochar) là một chất xốp có các gốc carbon và có nguồn gốc tù quá trình nhiệt phân sinh khối các loại chất thải, động, thực vật,... duới điều kiện hạn chế oxy hoạc không có oxy. Hiện nay biochar đã được ưng dụng rộng rãi trong xủ lý môi trương. Đặc biệt các biochar còn được chứng minh là có thể xư lý dầu diesel (diesel oil - DO) có trong đất và nước. Trong nghiên cứu này, chúng tôi sủ dụng 4 chủng vi khuẩn tạo màng sinh học tốt là Klepsiella sp. VTD8, Pseudomonas sp. BQN21, Rhodococcus sp. BN5 và Stenotropomonas sp. QND8 để gắn lên chất mang là biochar làm tù trấu nhằm đánh giá hiệu quả xủ lý DO của chúng. Kết quả cho thấy, sau 7 ngày, các chủng VTD8, BQN21, BN5 và QND8 có khả năng phân hủy 67, 73, 75 và $68 \%$ DO với hàm luợng ban đầu là $39 \mathrm{~g} / \mathrm{l}$. Trong khi đó, hiệu suất của màng sinh học tạo thành bởi hôn hợp các chủng này khi không có chất mang biochar trấu và khi có chất mang biochar trấu lần luợt là 78 và $98 \%$. Còn sủ dụng chất mang biochar trấu không có vi sinh vật làm đối chứng thì thu được hiệu suất hấp phu DO là $23 \%$. Nhu vậy, kết quả này mở ra tiềm năng ứng dụng biochar trấu làm chất mang cho các chủng vi khuẩn tạo màng sinh học để nâng cao hiệu quả xủ lý ô nhiếm dầu.

Keywords: Biochar, biodegradation, biofilm, diesel oil

\section{Introduction}

Diesel oil (DO) has become one of the most important energy sources in the world. However, contamination of water and soil by DO as results of exploration, production, maintenance, transportation, storage and accidental release, has caused significant environmental impacts and presents substantial hazards to human health [15]. Various existing clean-up approaches for the remediation of oil contaminated water and soil can be categorized into three general types: mechanical, chemical and biological treatment methods [5], [7]. Amongst, biodegradation of DO using microorganisms has increased in popularity in recent years [16], in that it is a clean method with the ad- 
vantages of being environmentally safe, cost-effective, and does not generate secondary waste. It is now confirmed to have much potential in removing diesel oil from contaminated sites [5]. The purpose of the present study was to prove high performance of naturally selfimmobilized cells on biochar produced from husk, biofilms, to remove DO from oil polluted waste-water and sediment.

Biochar is a porous, carbon-residue derived from the thermal conversion of waste biomass under limited oxygen or anaerobic conditions [11]. To date, there has been a various publications on the application of biochar in oil contaminated water and soil treatment [3], [4], [8]. Beesley et al. (2011) reviewed that biochar was able to enhance sorption of both organic and inorganic contaminants to their surfaces, reducing pollutant mobility when amending contaminated soils. Many polycyclic aromatic hydrocarbon components containing in oil were published to well sorption by biochar [1], [12].

Biofilms are communities of microorganisms formed on the surface of solid materials or interfaces [20]. It has recently been demonstrated that environmental microorganisms exist predominantly as biofilms and gain high tolerance to physical, chemical, and biological stresses [9]. Biofilm-forming bacteria were published to well degrade and transform DO, fuel oil and crude oil components [10], [18]. However, to our knowledge there is lack of literature that using biofilm-forming bacteria attacked to biochar to enhance DO removal. In this study, assessing biodegradation of DO by 4 biofilm-forming bacterial strains including Rhodococcus sp. BN5, Pseudomonas sp. BQN21, Stenotrophomonas sp. QND8 and Klibsiella VTD8 immobilized in husk biochar was conducted.

\section{Materials and methods}

\subsection{Bacterial strains}

We examined four hydrocarbon-degrading bacterial strains in the Environmental Biotechnology Laboratory, Institute of Biotechnology, VAST for their biofilm forming activities. Their characteristics are described in Table 1.

The Acinetobacter calcoaceticus P23 was given by Prof. Dr. Morikawa, Hokkaido University - Japan, and used as a positive control [21]

Table 1. Time and study sites

\begin{tabular}{cccccccc} 
No & Strain names & \multicolumn{3}{c}{ Substrates } & \multicolumn{2}{c}{ Place isolate } \\
\cline { 3 - 7 } & & DO & Naphthalene & Phenol & Pyrene & Toluene & Ha noi \\
\hline 1 & BN5 & +++ & ++ & +++ & +++ & +++ & Quang ninh \\
2 & BQN21 & +++ & + & +++ & + & +++ & Quang ngai \\
3 & QND8 & +++ & + & +++ & ++ & +++ & Vung tau \\
4 & VTD8 & +++ & ++ & +++ & ++ &
\end{tabular}

\subsection{Culture media}

Liquid MPA medium (Meat extract-3g, pepton-10g, $\mathrm{NaCl}-5 \mathrm{~g}$ and distilled water-1 liter at $\mathrm{pH}$ 7.0-7.2) was used for biofilm formation and for general cultivation of bacteria. Minimum mineral Gost medium $\left(\mathrm{Na}_{2} \mathrm{HPO}_{4}-0.7 \mathrm{~g}\right.$, $\mathrm{KH}_{2} \mathrm{PO}_{4}-0.3 \mathrm{~g}, \mathrm{KNO}_{3}-3 \mathrm{~g}, \mathrm{NaCl}-5 \mathrm{~g}, \mathrm{MgSO}_{4}-0.4 \mathrm{~g}$ and distilled water-1 liter at $\mathrm{pH}$ 7.0-7.2) was used for DO removal experiments.

Biochar was produced under limited oxygen by pyrolysis at $450{ }^{\circ} \mathrm{C}$.

\subsection{Methods}

\section{Identification}

Total bacterial DNAs of all strains were extracted as described by Zhou et al. (1996) [22] and were used as templates to amplify $16 \mathrm{~S}$ rRNA genes with specific primers 9f (5' -GAG TTT GAT CCT GGC TCA G -3') and 1525r (5'-AGA AAG GAG GTG ATC CAG CC-3'). Cycle of PCR reaction was: $94^{\circ} \mathrm{C}$ in 5 minutes; repeated 35 cycles $\left(94^{\circ} \mathrm{C}\right.$ in 30 seconds; $56^{\circ} \mathrm{C}$ in 30 seconds; $72^{\circ} \mathrm{C}$ in 2 minutes); $72^{\circ} \mathrm{C}$ in 5 minutes and $4^{\circ} \mathrm{C}$ to maintain. After- that, PCR products (about $1500 \mathrm{bp}$ ) were purified and the sequences were estimated by using automatic ABI PRISM 3100 Avant Gentic Analyzer machine. Nucleotide sequences were compared to the other in the Genbank (NCBI) in order to contribute phylogenetic tree by using Blast program, Bioedit, Clustal X and Mega4 softwares.

\section{Biofilm formation test}

The experiment was carried out by using the method described by Schimada et al. (2012) [18].

\section{Bacterial immobilization}

Cells of mixed strains (BN5, BQN21, QND8 and VTD8 mixed with equal proportions) were cultured in a MPA medium. $5 \mathrm{~mL}$ of cell suspension with turbidity of 1.0 at O.D600 nm was washed with phosphate buffer and resuspended in $100 \mathrm{~mL}$ MPA medium for $24 \mathrm{~h}$ at $30{ }^{\circ} \mathrm{C}$ to obtain approximately $2 \times 10^{9} \mathrm{CFU}$. This cell suspension was then inoculated in $100 \mathrm{ml}$ MPA medium with $1.5 \mathrm{~g}$ of husk biochar submerged in it. This co-culture was incubated at $30{ }^{\circ} \mathrm{C}$ for $120 \mathrm{~h}$ under static conditions to allow the biofilm to develop on the carrier surfaces. Every $48 \mathrm{~h}$, 
the spent medium was removed and replaced with fresh medium.

\section{DO removal by immobilized cells on carriers}

Approximately $1 \mathrm{~g}$ (wet weight) of biofilm-each strain and mixed strains, were placed over $10 \mathrm{ml}$ artificial sea water (ASW) spiked with $39 \mathrm{~g} / \mathrm{L}$ DO in $100 \mathrm{ml}$ glass flasks with rubber stoppers to avoid oxygen and oil volatilization. The removal assay lasted standing for 7 days. After 7 day-incubation, two samples were taken separately: 1) the oil remaining in the liquid, and 2) the sorbed oil on husk biochar and bacterial biofilm. The two samples were extracted with hexane until no color was observed in the organic phase. The hexane was then allowed to evaporate from the extract at room temperature and the residual oil was determined gravimetrically. The same procedure was followed using only husk biochar (sterile husk biochar submerged in ASW spiked with $39 \mathrm{~g} / \mathrm{L} \mathrm{DO}$ ) as abiotic control.

\section{Counting the number of cells}

For biofilm quantification, the method described by Allessandrello et al. (2017) [2]. Briefly, one gram biochar with immobilized cells were taken and washed twice with $5 \mathrm{ml}$ saline solution $(\mathrm{NaCl} 0.9 \% \mathrm{w} / \mathrm{v})$ to remove the planktonic cells. The pieces were suspended in $5 \mathrm{ml}$ saline and vigorously vortexed for $10 \mathrm{~min}$ to detach the cells. This suspension was diluted, and dilutions were plated in solid MPA medium. The plates were incubated at $30 \pm 2{ }^{\circ} \mathrm{C}$ for 5 days when the colonies of 4 strains were clearly distinguished from each other and could be counted. Logarithmic $\mathrm{CFU} / \mathrm{mL}$ values for single biofilm and mixed biofilm without carrier assays as well as logarithmic $\mathrm{CFU} / \mathrm{g}$ values for biofilm formed on carrier assays (then we call CFU values) of each strain present in the biofilms were counted.

\section{Scanning electron microscope SEM}

To clearly identify bacteria, scanning electron microscopy (SEM, JSM-840, Japan) of bacteria immobilized in carriers was conducted, the method described by Le Thi Nhi Cong et al. (2014) [14].

\section{DO degradation}

DO degradation capacity was estimated by standard method of TCN 102-97. The analysis process was performed in co-ordination with Institute of Industrial Chemistry.

Each experiment was performed in triplicate.

\section{Results and discussion}

\subsection{Identification}

Based on the results of the $16 \mathrm{~S}$ rRNA gene analysis, 4 selected strains were named as Rhodococcus sp. BN5, Pseudomonas sp. BQN21, Stenotrophomonas sp. QND8 and Klibsiella VTD8 (Fig. 1).
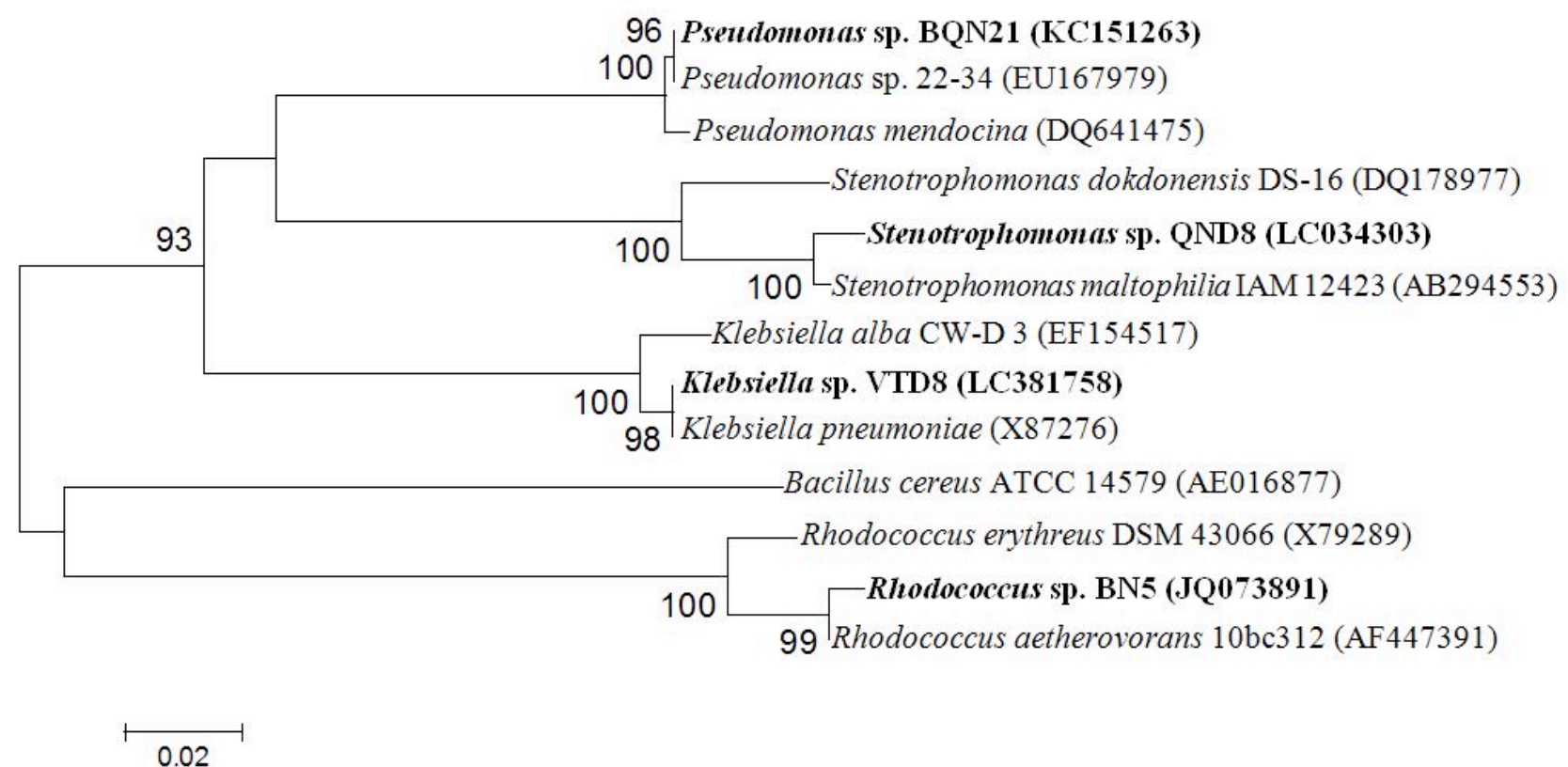

Fig 1. Dendrogram depicting the phylogenetic relationships of four biofilm-forming bacterial strains based on 16S rRNA gene sequence analysis. Numbers at nodes are confidence values of bootstrap analyses with 100 resamplings. Bar, 2 nucleotide substitution per 100 nucleotides

\subsection{Biofilm formation}

Biofilm formation ability was examined for the 4 strains as well as for a control without any strain. The Acinetobacter calcoaceticus P23 was used as a positive control
[21]. Each strain was grown in a $1.5-\mathrm{mL}$ polypropyrene tube without shaking for 24, 48 and $72 \mathrm{~h}$ in MPA liquid medium. The obtained results were shown in Fig. 2.

Fig. 2 indicated that in comparison with positive control, the P23, all 4 well hydrocarbon-degrading bacterial 
strains have high biofilm formation capacity. Thus, we chose all 4 strains BN5, BQN21, QND8 and VTD8 as model biofilm-forming strains for further investigation.

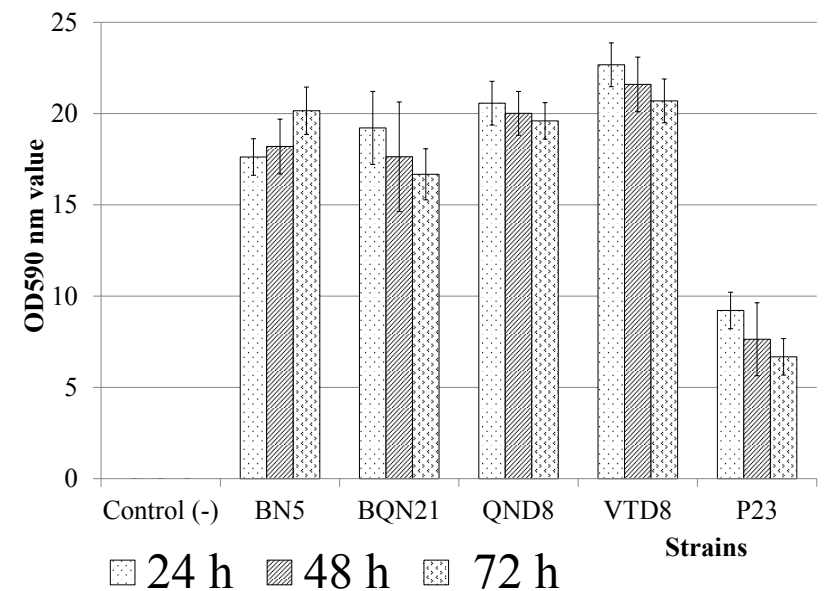

Fig. 2. Amount of biofilm formed by 4 hydrocarbondegrading strains and Acinetobacter calcoaceticus P23 measured by using the crystal violet staining method. Acinetobacter calcoaceticus $\mathrm{P} 23$ was used as a positive control, and $K$ is negative control (without inoculation) [21]. Error bar represents standard deviation $(\mathbf{n}=3)$.

\subsection{Counting cells}

Biofilm formation by single strain and by mixed species with or without carriers was quantified before and after the diesel oil removal assay. Fig 3. shows the logarithmic CFU values of each strain present in the biofilms. Initial bacterial counts at day 0 were the same number with $8 \times 10^{2}(\mathrm{CFU} \mathrm{m} / \mathrm{L})(\mathrm{SD}=13)$. After 7 day - incubation with initial concentration diesel oil of $39 \mathrm{~g} / \mathrm{L}$, high numbers of CFU of each strain were obtained, approx. 7.93 log units. Almost small change in cultivable numbers of each strain were observed in single biofilm, in mixed biofilm and those attached to husk biochar.

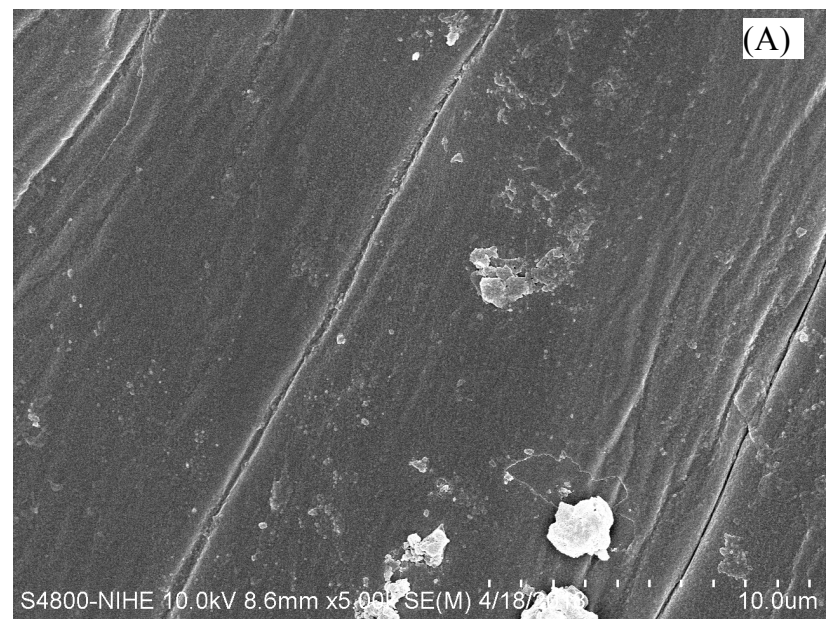

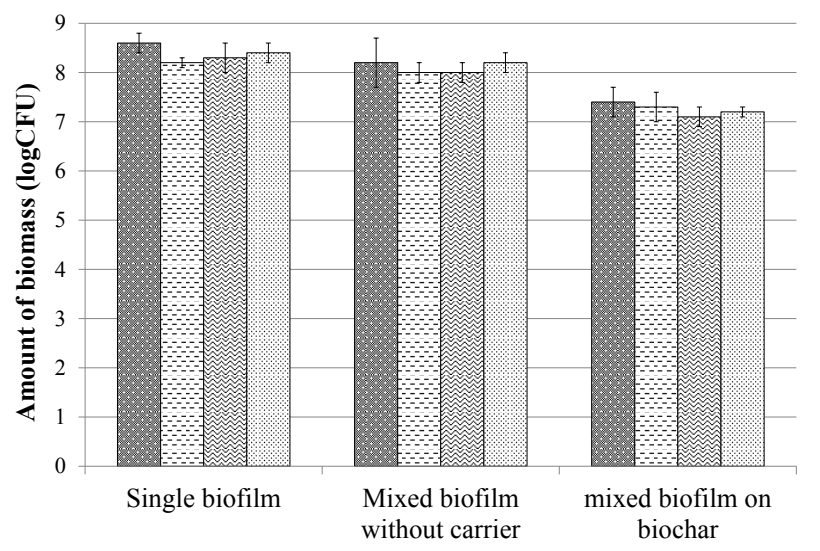

BN5 圈BQN21 图QND8 $\square \mathrm{VTD} 8$

Fig. 3. Cell viability of the 4 strains BN5, BQN21, QND8 and VTD8 that compose the biofilm formed in different condition including single biofilm of each strain, mixed biofilm without carrier and mixed biofilm attached on husk biochar. Viable cell counts were determined and after 7 days incubation with DO. Error bar represents the standard deviation $(n=3)$.

\subsection{Scanning electronic microscopy of sup- port materials and immobilized cells}

Scanning electronic microscope (SEM) micrographs of the husk biochar without and with mixed species biofilm are shown in Fig. 4. The photograph showed that the husk biochar had high porosity, which allowed good adsorption of cells onto the carrier. The immobilization of cells in husk biochar was confirmed by SEM, and the images are shown in Fig. 4B. The photograph evidently showed that the bacteria were firmly immobilized on the husk biochar, as seen by their coccus and rod shape of approximately $5 \mu \mathrm{m}$ in length and $1 \mu \mathrm{m}$ in diameter. Furthermore, biochar produced from the thermal conversion of husk under limited oxygen or anaerobic conditions was selected because of its organic, nontoxic and nonpolluting nature, and its ubiquity makes the application possible on a global perspective [1], [8], [4].

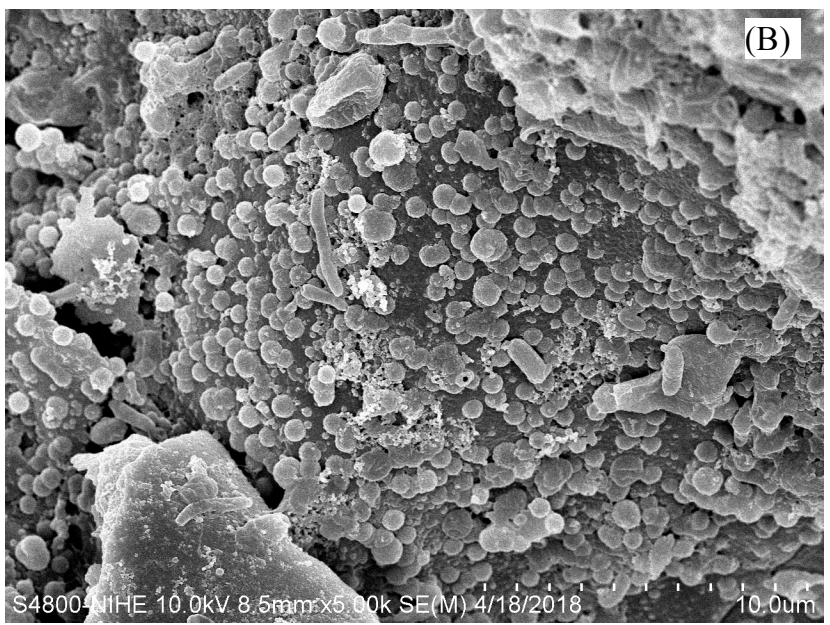

Fig. 4. Scanning electron microscopic (SEM) images of the biocarriers without the bacteria (A) and with the consortium colonizing the surface of the biocarriers $(\mathrm{B})$. 


\subsection{Diesel oil degradation}

The efficiency of the isolated bacteria for diesel oil degradation was individually evaluated by standard method of TCN 102-97. The capacity of the selected bacteria to degrade diesel was first conducted by separately cultivating them as biofilms of each strain. Different profiles of degradation were detected, as shown in Fig 5. The results elucidated that biofilms formed by the VTD8, BQN21, BN5 and QND8 degraded 67, 73, 75 and $68 \%$ of the DO after 7 days using an initial concentration of $39(\mathrm{~g} / \mathrm{L})$. Additionally, all 4 selected strains possessed similar levels of growth and diesel oil degradation. Using a mixedspecies biofilm without carrier or with husk biochar carrier, 78 and $98 \%$ of the diesel oil was degraded after 7 days. Meanwhile, using husk biochar without bacteria as absortion control, the amount of DO removal was $23 \%$.

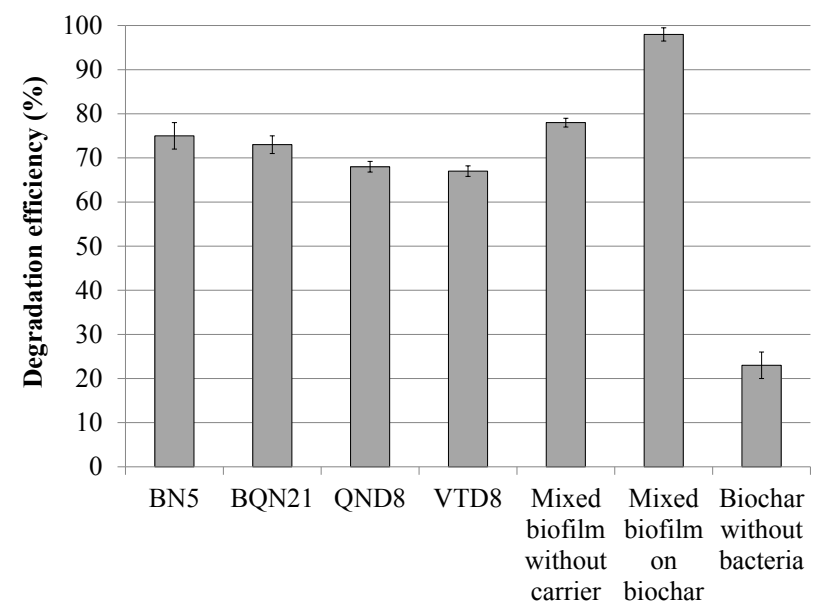

Fig. 5. Effieciency of diesel oil degraded by each strain in single- or mixed-species biofilm without carrier and mixed species biofilm with carrier, husk biochar. Error bar represents the standard deviation $(n=3)$.

Recently, various research reports have been devoted to investigate the application of using immobilized microorganisms on biochar for pollutants removal from aqueous and solid solutions [7], [8], [11], [19]. Chen et al. (2016) used modified bamboo charcoal as a cheap, abundant and alternative cell immobilization matrix for biodegrading diesel oil. As a result, Acinetobacter venetianus immobilized on modified bamboo charcoal demonstrated superior efficiency in degrading diesel oil (94\%) compared to planktonic cells culture ( $82 \%$ ) with the initial concentration of $200 \mathrm{mg} / \mathrm{L}$ over a 3-day period. Oleszczuk et al. (2012) published that the freely dissolved concentration of PAH in sewage sludge can significantly decrease in the presence of biochar, with the $0-57 \%$ reduction depending on the added amount of biochar [17]. Other pollutants in environment such as radionuclide [13], heavy metals [3] can also be amended by biofilm-forming bacteria on biochar. In recent years, the retention of agricultural wastes is one of the increasing significant environmental concerns as enormous amounts of organic wastes are created with the intensive agricultural activities. Agricultural wastes such as crop straw and animal manure are plentiful in organic component and other elements that plant needs, so it is favorable to improve them to agricultural land with the view to amend soil property, which can help to recycle nutrient and increase soil organic matter level and consequently improve soil characteristics [11]. However, to our knowledge there is no publication on application of husk biochar as carrier to immobilize bacteria for enhancement DO removal purpose. The results of this study indicated that using four biofilm-forming bacterial strains such as BN5, BQN21, QND8 and VTD8 attack to husk biochar could remarkably increase DO degradation efficiency.

\section{Conclusion}

In this study the cells immobilized on husk biochar were conducted to degrade diesel oil. A removal efficiency of $98 \%$ was achieved when dealing with diesel oil at $39 \mathrm{~g} / \mathrm{L}$ with treatment time lasting 7 days. Meanwhile, biofilm formed by single species including Klibsiella VTD8, Pseudomonas sp. BQN21, Rhodococcus sp. BN5, Stenotrophomonas $\mathrm{sp}$. QND8 and mixed species could degrade $67,73,75,68$ and $78 \%$. This high removal efficiency was probably due to combining the adsorption and biodegradation processes. These results have confirmed that agricultural wastes such as husk may be used to produce biochar to enhance diesel oil adsorption and degradation. Husk biochar can potentially be a relatively cost-effective and environmental beneficial tool for environmental remediation. Another important reason for choosing husk biochar as a carrier is its high surface area and porosity, which are suitable for the initial rapid colonization of microbes. SEM has shown that the cells of 4 biofilmforming bacterial strains BN5, BQN21, QND8 and VTD8 are easily attached to the surface and inner space of husk biochar. This study has therefore provided further substantial knowledge regarding the role husk biochar plays in the environment. Finally, it is possible to develop bioremediation strategies for diesel oil polluted sites by taking advantage of both adsorption and biodegradation of husk biochar.

Acknowledgement: This research is funded by Institute of Biotechnology, VAST under grant number CS18-07.

\section{References}

[1] Ahmad, M., Rajapaksha, A.U., Lim, J.E., Zhang, M., Bolan, N., Mohan, D., Vithanage, M, Le S.S., Ok, Y.K. (2014) Biochar as a sorbent for contaminant management in soil and water: A review. Chemosphere 99, 19-33.

[2] Alessandrello, M.J., Tomás, M.S.J., Raimondo, E.E., Vullo, D.L., Ferrero, M.A. (2017) Petroleum oil removal by immobilized bacterial cells on polyurethane foam under different temperature conditions. Mar Pollut Bull, 122(1-2), 156-160.

[3] Beesley, L., Jiménez, E.M., Eyles, J.L.G. (2010). Effects of biochar and greenwaste compost amendments on mobility, bioavailability and toxicity of inorganic and organic contaminants in a multi-element 
polluted soil. Environ Pollut 158, 2282-2287.

[4] Beesley, L., Moreno-Jimenez, E., Gomez-Eyles, J.L., Harris, E., Robinson, B., Sizmur, T. (2011). A review of biochars' potential role in the remediation, revegetation and restoration of contaminated soils. Environ Pollut 159: 3269-3282.

[5] Bento, F.M., Camargo, F.A.O., Okeke, B.C., Frankenberger, W.T. (2005) Comparative bioremediation of soils contaminated with diesel oil by natural attenuation, biostimulation and bioaugmentation. Bioresour Technol 96, 1049-1055.

[6] Chen, C., Zhou, W., Lin, D. (2015). Sorption characteristics of $\mathrm{N}$-nitrosodimethylamine onto biochar from aqueous solution. Bioresour Technol 179, 359366.

[7] Chen, Y., Yu, B., Lin, J., Naidu, R., Chen, Z. (2016) Simultaneous adsorption and biodegradation (SAB) of diesel oil using immobilized Acinetobacter venetianus on porous material. Chem Eng J 289, 463470.

[8] Duku, M., Gu, S., Hagan, E. (2011). Biochar production potential in Ghana-a review. Renew Sustain Energ Rev, 15(8), 3539-3551.

[9] Gorbushina, A.A., Broughton, W.J., (2009) Microbiology of the atmosphere-rock interface. How biological interactions and physical stresses modulate a sophisticated microbial ecosystem. Annu Rev Microbiol 63, 431-450.

[10] Hou, D., Shen, X., Luo, Q., He, Y., Wang, Q., Liu, Q. (2013) Enhancement of the diesel oil degradation ability of a marine bacterial strain by immobilization on a novel compound carrier material. Marine Pollut Bull 67, 146-151.

[11] Inyang, M., Dickenson, E. (2015). The potential role of biochar in the removal of organic and microbial contaminants from potable and reuse water: A review. Chemosphere 134, 232-240.

[12] Khan, S., Wang, N., Reid, B.J., Freddo, A., Cai, C., 2013a. Reduced bioaccumulation of PAHs by Lactuca satuva L. grown in contaminated soil amended with sewage sludge and sewage sludge derived biochar. Environ. Pollut. 175, 64-68.
[13] Kumar, S., Loganathan, V. A., Gupta, R. B., Barnett, M. O. (2011) An assessment of U(VI) removal from groundwater using biochar produced from hydrothermal carbonization, J Environ Manage 92, 25042512 .

[14] Le Thi Nhi Cong, Cung Thi Ngoc Mai, Vu Thi Thanh, Le Phi Nga, Nghiem Ngoc Minh (2014). Application of a biofilm formed by a mixture of yeasts isolated in Vietnam to degrade aromatic hydrocarbon polluted wastewater collected from petroleum storage. Water Sci Technol 70(2), 329-336.

[15] Lee, Y.C., Shin, H.J., Ahn, Y., Shin, M.C., Lee, M., Yang, J.W. (2010) Biodegradation of diesel by mixed bacteria immobilized onto a hybrid support of peat moss and additives: a batch experiment. J Hazard Mater 183, 940-944.

[16] Nano, G., Borroni, A., Rota, R. (2003) Combined slurry and solid-phase bioremediation of diesel contaminated soils. J Hazard Mater 100, 79-94.

[17] Oleszczuk, P., Hale, S. E., Lehmann, J., Cornelissen, G. (2012) Activated carbon and biochar amendments decrease pore-water concentrations of polycyclic aromatic hydrocarbons (PAHs) in sewage sludge, Bioresour Technol, 111, 84-91.

[18] Shimada, K., Itoh, Y., Washio, K., Morikawa, M. (2012) Efficacy of forming biofilms by naphthalene degrading Pseudomonas stutzeri T102 toward bioremediation technology and its molecular mechanisms. Chemosphere 87, 226-233.

[19] Tang, J., Zhu, W., Kookana, R., Katayama, A. (2013). Characteristics of biochar and its application in remediation of contaminated soil. J Biosci Bioeng, 111(6), 653-659.

[20] Watnick, P., Kolter, R., (2000) Biofilms, city of microbes. J Bacteriol 13, 20-26.

[21] Yamaga, F., Washio, K., Morikawa, M. (2010) Sustainable biodegradation of phenol by Acinetobacter calcoaceticus P23 isolated from the rhizosphere of duckweed Lemna aoukikusa. Environ Sci Technol 44, 6470-6474.

[22] Zhou J., Bruns M. A., Tiedje J. M., 1996. DNA Recovery from soils of diverse composition. Appl. Environ. Microbiol. 62(2), 316-322. 